\title{
Pengalaman Auditor dan Kepuasan Kerja Sebagai Pemoderasi Pengaruh TBP dan Profesionalisme Pada Kualitas Audit
}

\author{
I Gusti Diah Agung Prabawati $\mathbf{S}^{1}$ \\ Ni Luh Sari Widhiyani ${ }^{2}$
}

\author{
${ }^{1,2}$ Fakultas Ekonomi dan Bisnis Universitas Udayana (Unud), Bali, Indonesia \\ e-mail: prabawatisuteja@gmail.com
}

\begin{abstract}
ABSTRAK
Penelitian ini bertujuan untuk mengetahui pengaruh time budget pressure (TBP) dan profesionalisme pada kualitas audit dengan pengalaman auditor dan kepuasan kerja sebagai pemoderasi di KAP di Bali. Populasi dalam penelitian ini adalah seluruh auditor yang bekerja di KAP di Bali yang berjumlah 77 auditor. Penentuan sampel dalam penelitian ini menggunakan metode non probability sampling dengan teknik purposive sampling. Sampel berjumlah 42 auditor. Metode pengumpulan data yang digunakan adalah metode survei dengan instrumen kuesioner. Hasil dari kuesioner penelitian ini diukur dengan menggunakan skala likert. Teknik analisis data yang digunakan adalah Moderated Regression Analysis. Hasil penelitian ini menunjukkan bahwa time budget pressure berpengaruh negatif dan signifikan pada kualitas audit; profesionalisme berpengaruh positif dan signifikan pada kualitas audit; pengalaman auditor memperlemah pengaruh time budget pressure pada kualitas audit, dan memperkuat pengaruh profesionalisme pada kualitas audit; serta kepuasan kerja memperlemah pengaruh time budget pressure pada kualitas audit, dan memperkuat pengaruh profesionalisme pada kualitas audit.
\end{abstract}

Kata kunci: time budget pressure, profesionalisme, pengalaman auditor, kepuasan kerja, kualitas audit

\begin{abstract}
This study aims to determine the effect of time budget pressure (TBP) and professionalism on audit quality with auditor experience and job satisfaction as moderating in KAP in Bali. The population in this study were all auditors who worked in KAP in Bali, amounting to 77 auditors. Determination of samples in this study using non probability sampling method with purposive sampling technique. The sample amounted to 42 auditors. The results of this research questionnaire were measured using a Likert scale. The data analysis technique used is Moderated Regression Analysis. The results of this study indicate that time budget pressure has a negative and significant effect on audit quality; professionalism has a positive and significant effect on audit quality; auditor experience weakens the effect of time budget pressure on audit quality, and strengthens the influence of professionalism on audit quality; and job satisfaction weakens the effect of time budget pressure on audit quality, and strengthens the influence of professionalism on audit quality.

Keywords: time budget pressure, professionalism, auditor experience, job satisfaction, audit quality
\end{abstract}


I Gusti Diah Agung Prabawati S. dan Ni Luh Sari Widhiyani. Pengalaman...

\section{PENDAHULUAN}

Kualitas audit merupakan hal yang sangat penting. Kualitas audit yang tinggi diharapkan dapat menjadikan laporan keuangan sebagai sarana yang relevan bagi para pemangku kepentingan untuk mengambil keputusan. Kualitas audit yang tinggi artinya laporan keuangan perusahaan tersebut dapat dipertanggungjawabkan dan sesuai dengan SAK yang berlaku. DeAngelo (1981) menyatakan bahwa kualitas audit sebagai kemungkinan dimana auditor akan menemukan dan melaporkan pelanggaran yang ada dalam sistem akuntansi. Melihat berbagai fenomena terkait manipulasi laporan keuangan dan kinerja yang buruk pada auditor membuat kualitas audit menjadi salah satu hal yang harus diperhatikan baik oleh masyarakat, perusahaan, dan auditor itu sendiri.

Kualitas audit menjadi isu yang semakin penting karena keraguan terhadap profesi akuntan publik semakin meningkat. Kegagalan profesi akuntan publik terkait skandal telah merusak citra profesi akuntan publik (Barrainkua dan Espinosa Pike, 2018). Hal ini dikarenakan banyak terjadi kasus kelalaian dalam mengaudit laporan keuangan yang dilakukan oleh beberapa Kantor Akuntan Publik (KAP) ternama seperti misalnya pada tahun 2017 Mitra Ernst \& Young's (EY) di Indonesia yaitu KAP Purwanto, Suherman \& Suja didenda sebesar Rp 13 miliar oleh regulator Amerika Serikat, akibat divonis gagal melakukan audit laporan keuangan kliennya. Menurut PCAOB KAP tersebut lalai dalam menjalankan tugas dan fungsinya untuk memperoleh bukti yang audit yang cukup sehingga berimbas pada opini yang dikeluarkan untuk laporan keuangan kliennya (Bisnistempo 2017). 
Salah satu faktor yang dapat memengaruhi kualitas audit adalah time budget pressure. Pada umumnya setiap Kantor Akuntan Publik (KAP) wajib memiliki estimasi waktu yang diperlukan dalam proses auditnya. Anggaran waktu memiliki peran yang sangat penting karena akan menentukan besarnya kos audit yang dibayarkan oleh klien. Lamanya anggaran waktu dapat membuat kos audit menjadi tinggi dan efektivitas proses audit yang rendah. Tingginya kos audit yang dibayarkan klien dapat menjadi pertimbangan klien untuk berpindah ke KAP lain.

Anggaran waktu yang dibuat oleh KAP terkadang sangat ketat. Ketatnya anggaran waktu menyebabkan tingginya tekanan yang dihadapi oleh auditor. Bahkan tidak jarang sempitnya anggaran waktu mengakibatkan stres kerja yang dihadapi oleh seorang auditor. Stres kerja yang tinggi akan memengaruhi kualitas audit yang dihasilkan (Yan dan Xie, 2016). Time budget pressure akan memengaruhi kinerja auditor dalam mengambil keputusan saat melaksanakan prosedur audit (Arisinta 2013). Putra (2013) menyatakan bahwa tingginya time budget pressure dapat menyebabkan penurunan kualitas audit. Tekanan yang timbul dari anggaran waktu yang ketat, dapat membuat auditor mengerjakan tugas dengan terburu-buru. Svanström (2016) menyatakan bahwa time budget pressure akan membuat auditor cenderung berperilaku disfungsional. Contoh perilaku yang dilakukan auditor akibat tingginya time budget pressure antara lain terlalu percaya penjelasan dan presentasi klien, melakukan premature sign off, dan gagal menginvestigasi isu-isu yang relevan. Tingginya time budget pressure menyababkan auditor mengurangi sampel pemeriksaan (Riyandari dan Badera, 2017) 
I Gusti Diah Agung Prabawati S. dan Ni Luh Sari Widhiyani. Pengalaman...

Hasil penelitian terdahulu menyatakan bahwa time budget pressure berpengaruh negatif pada kualitas audit, artinya semakin tinggi time budget pressure maka semakin rendah kualitas audit yang dihasilkan (Kurnia dkk., 2014). Hal ini juga sejalan dengan penelitian yang dilakukan oleh Santhi dan Ratnadi (2017), (Broberg et al., 2016), Putra (2013), serta Ningsih dan Yaniartha (2013). Hasil yang berbeda ditemukan oleh Jelista (2015) dan Arisinta (2013) menyatakan bahwa time budget pressure memiliki pengaruh positif dan juga signifikan pada kualitas audit.

Faktor lain yang dapat memengaruhi kualitas audit selain time budget pressure adalah profesionalisme. Profesionalisme merupakan suatu konsep untuk mengukur bagaimana para profesional memandang profesi mereka yang dapat dilihat dari sikap dan perilaku mereka sebagai seorang auditor (Lesmana dan Machdar, 2015). Profesionalisme adalah salah satu syarat yang harus dipenuhi dan dimiliki oleh seorang auditor karena akan berdampak kepada sikap dan ketangguhan dalam menjalankan profesi sebagai auditor independen (Surtikanti dan Lestary, 2012). Seorang auditor yang menjunjung tinggi profesionalisme dapat dilihat dari hasil auditnya. Sebagai seorang auditor profesional, dalam menjalankan proses audit dan penyusunan laporan keuangan seorang auditor wajib menggunakan kemahiran profesionalnya dengan cermat dan seksama. Menurut Heyrani et al. (2016) profesionalisme auditor berpengaruh pada pendapat auditor.

Hasil penelitian Agusti dan Pertiwi (2013) menyatakan bahwa profesionalisme auditor berpengaruh positif terhadap kualitas audit. Hasil yang 
sejalan juga ditemukan oleh Purwaningsih dan Suputra (2018). Namun hasil yang berbeda ditemukan oleh Futri dan Juliarsa (2014) serta Suardinatha dan Wirakusuma (2016) yang menyatakan bahwa profesionalisme tidak berpengaruh terhadap kualitas audit.

Masih adanya hasil-hasil penelitian yang berbeda terkait pengaruh satu variabel terhadap variabel lain kemungkinan ditentukan oleh faktor-faktor yang bersifat situasional (kontekstual) atau lebih dikenal sebagai variabel kontinjensi (Govindarajan, 1986). Variabel kontijensi yang digunakan dalam penelitian ini adalah pengalaman auditor dan kepuasan kerja. Pengalaman auditor dan kepuasan kerja memiliki hubungan dengan kualitas audit.

Pengalaman auditor merupakan faktor yang penting dimiliki oleh seorang auditor. Auditor yang mengaudit laporan keuangan diharapkan sudah memiliki pengalaman yang cukup, memenuhi kualifikasi sebagai seorang auditor dan memiliki pengetahuan tentang industri bisnis kliennya. Kuntari dkk. (2017) dan Hanjani dan Rahardja (2014) menyatakan bahwa pengalaman auditor berpengaruh positif pada kualitas audit. Lamanya seorang auditor bekerja dapat memengaruhi tindakannya dalam menangani stres kerja terkait ketatnya anggaran waktu dan lebih teliti sehingga mengurangi tingkat kelalaian seorang auditor.

Menurut Suyanti dkk. (2016) pengalaman yang dimiliki auditor berpengaruh pada kualitas audit. Semakin lama auditor bekerja maka semakin banyak pula audit yang dilakukan dan terbiasa dalam menemui kasus-kasus yang sifatnya kompleks. Auditor yang kurang berpengalaman akan berbeda dengan auditor yang telah berpengalaman. Perbedaan tersebut akan terlihat dalam hal 
I Gusti Diah Agung Prabawati S. dan Ni Luh Sari Widhiyani. Pengalaman...

menemukan dan melakukan kesalahan. Auditor yang telah berpengalaman akan mudah dalam mendeteksi kesalahan, memahami dan mengetahui penyebab kesalahan, serta keputusan apa yang seharusnya diambil untuk memecahkan masalah tersebut. Riyandari dan Badera (2017) menyatakan bahwa auditor yang berpengalaman atau tidak akan mampu untuk mendeteksi sesuatu yang sifatnya umum, namun ketika terjadi sesuatu yang sifatnya tidak umum auditor yang kurang berpengalaman tidak akan mampu mendeteksinya. Auditor yang kurang berpengalaman hanya fokus pada bagian audit yang diberikan sesuai dengan anggaran waktu dan kurang peduli pada proses audit secara keseluruhan (Herda dan Martin, 2016).

Kepuasan kerja juga harus dimiliki oleh seorang akuntan publik. Kepuasan kerja yang dimiliki oleh seorang auditor akan memengaruhi sikap dan perilakunya dalam bekerja dan bedampak pada kualitas audit yang dihasilkannya. Kepuasan kerja erat kaitannya dengan pemenuhan keinginan seseorang ditempat kerja, baik berupa gaji maupun fasilitas yang memadai. Hal tersebut dapat menjadi stimulus bagi auditor untuk selalu bekerja dengan baik terlepas dari kondisi apapun yang tengah dihadapinya. Semakin tinggi tingkat kepuasan auditor dalam bekerja, maka semakin meningkat pula kualitas auditnya (Luthans, 2015:121).

Kepuasan kerja menurut Iskandar dan Indarto (2014) merupakan suatu keadaan emosional individu, dimana keadaan tersebut menyenangkan atau tidak menyenangkan menurut sisi dan pandangan karyawan itu sendiri. Rasa senang akan datang ketika seseorang merasa puas dengan pekerjaan yang dijalaninya, terlepas dari rasa tertekan, sehingga akan menimbulkan rasa aman dan nyaman 
untuk selalu bekerja di lingkungan kerjanya (Tranggono dan Kartika, 2008). Hasil penelitian Futri dan Juliarsa (2014) menyatakan bahwa kepuasan kerja auditor berpengaruh positif terhadap kualitas audit.

Teori keagenan menjelaskan hubungan yang tercipta antara principal dan agent serta menjelaskan tentang bagaimana hubungan tersebut akhirnya melahirkan asimetri informasi dan konflik kepentingan. Menurut teori keagenan, principal mendelegasikan wewenang kepada agent. Berdasarkan teori keagenan maka diperlukan pihak yang mampu menjembatani hubungan antara principal dan agent untuk meminimalisir asimetri informasi. Pihak tersebut adalah auditor independen yang dalam hal ini adalah akuntan publik. Asimetri informasi dapat diminimalisir dengan adanya kualiitas audit yang dihasilkan oleh auditor.

Teori keperilakuan menjelaskan bahwa terdapat beberapa faktor yang memengaruhi tindakan seseorang. Faktor-faktor tersebut adalah faktor luar dan faktor dalam. Faktor dalam adalah faktor yang berhubungan dengan respon seseorang dalam menanggapi suatu kejadian. Faktor luar adalah faktor yang berasal dari luar berupa stimulus yang dapat mengubah tindakan seseorang (Maryani dan Ludigdo, 2001). Time budget pressure, profesionalisme, pengalaman auditor, dan kepuasan kerja dapat menjadi faktor-faktor yang memengaruhi kualitas audit.

Tugas-tugas audit yang tidak realistis dengan anggaran waktu dapat mengakibatkan auditor melakukan tindakan yang dapat menurunkan kualitas audit (Indrajaya dkk., 2017). Coram et al. (2003) menemukan bahwa menurunnya kualitas audit dikarenakan anggaran waktu yang ketat. Salah satu respon yang 
I Gusti Diah Agung Prabawati S. dan Ni Luh Sari Widhiyani. Pengalaman...

diberikan auditor ketika menghadapi time budget pressure adalah berperilaku disfungsional (Mangiwa et al., 2017). Perilaku disfungsional auditor dapat mengurangi kualitas audit secara langsung (Umar et al., 2017). Broberg et al. (2016) mengemukakan bahwa time budget pressure menurunkan kualitas audit yang dihasilkan auditor. Penelitian yang dilakukan oleh Kurnia dkk. (2014), Santhi dan Ratnadi (2017), dan Putra (2013) juga menyatakan bahwa time budget pressure berpengaruh negatif pada kualitas audit. Berdasarkan paparan diatas baik teori dan beberapa penelitian sebelumnya tentang pengaruh time budget pressure pada kualitas audit, maka hipotesis 1 (satu) dinyatakan sebagai berikut:

$\mathrm{H}_{1}$ : Time budget pressure berpengaruh negatif pada kualitas audit.

Seorang auditor yang profesional artinya adalah tanggung jawab dan berprilaku lebih baik dari sekedar mematuhi undang-undang, kode etik, dan peraturan yang ada (Futri dan Juliarsa, 2014). Tanggung jawab dalam berperilaku dapat tercermin dari bagaimana seorang auditor menjalankan tugasnya. Seorang auditor yang memiliki sikap profesionalisme yang tinggi akan selalu menjalankan tugasnya sesuai dengan prosedur dan standar yang ada dalam profesi akuntan publik sehingga akan meningkatkan kualitas audit yang dihasilkannya. Hal ini berati bahwa kualitas audit lahir dari seorang auditor yang selalu menjunjung tinggi standar profesi akuntan publik ketika melaksanakan tugasnya.

Hasil penelitian Agusti dan Pertiwi (2013) menyatakan bahwa profesionalisme auditor berpengaruh pada kualitas audit. Hasil yang sejalan juga ditemukan oleh Lesmana dan Machdar (2015) dan Purwaningsih dan Suputra (2018) menemukan hasil yang sama yaitu profesionalisme auditor berpengaruh 
positif pada kualitas audit. Berdasarkan paparan diatas baik teori dan beberapa penelitian sebelumnya tentang pengaruh profesionalisme pada kualitas audit, maka hipotesis 2 (dua) dinyatakan sebagai berikut:

$\mathrm{H}_{2}$ : Profesionalisme berpengaruh positif pada kualitas audit.

Coram et al. (2003) menemukan bahwa menurunnya kualitas audit dikarenakan anggaran waktu yang ketat. Penelitian yang telah dilakukan sebelumnya mendapatkan hasil yaitu Ningsih dan Yaniartha (2013) menyatakan bahwa time budget pressure berpengaruh negatif pada kualitas audit. Hal tersebut konsisten dengan penelitian yang dilakukan oleh Riyandari dan Badera (2017).

Semakin banyak pengalaman yang dimiliki auditor maka akan semakin dapat menghasilkan berbagai dugaan dalam menjelaskan temuan audit (Libby dan Frederick, 1990). Auditor yang memiliki pengalaman yang cukup akan memiliki kemampuan yang berkaitan dengan teknik-teknik audit dan kemampuan dalam masalah audit yang bersifat umum maupun khusus, sehingga mampu menyikapi dan terbiasa menghadapi situasi yang timbul akibat time budget pressure. Hal tersebut dapat mengakibatkan auditor akan tetap mampu menghasilkan kualitas audit yang baik. Penelitian yang dilakukan oleh Riyandari dan Badera (2017) menemukan bahwa pengalaman auditor mampu memoderasi pengaruh time budget pressure pada kualitas audit. Berdasarkan paparan diatas baik teori dan beberapa penelitian sebelumnya, maka hipotesis 3 (tiga) dinyatakan sebagai berikut:

$\mathrm{H}_{3}$ : Pengalaman auditor memperlemah pengaruh time budget pressure pada kualitas audit. 
I Gusti Diah Agung Prabawati S. dan Ni Luh Sari Widhiyani. Pengalaman...

Seorang auditor akan memiliki kinerja yang lebih baik jika mempunyai sikap profesionalisme (Anggreni dan Rasmini, 2017). Penelitian sebelumnya yang dilakukan oleh Dewi dan Muliartha (2018) menemukan bahwa profesionalisme berpengaruh positif pada kualitas audit. Hasil yang sejalan juga ditemukan oleh Kristianto dan Hermanto (2017).

Pengalaman yang dimilki oleh auditor akan membuat auditor semakin paham dengan standar profesi akuntan publik sehingga akan memengaruhi sikap auditor dalam melaksanakan pekerjaannya. Seorang auditor yang profesional dan ditambah dengan pengalaman yang dimiliki maka akan membuat kualitas audit yang dihasilkannya semakin baik. Penelitian yang dilakukan oleh Annisa dan Wirakusuma (2016) mengenai pengalaman auditor sebagai variabel moderasi terhadap hubungan antara faktor individu dan kualitas audit menunjukkan bahwa pengalaman auditor berpengaruh untuk memoderasi hubungan due professional care dan kualitas audit. Berdasarkan paparan diatas baik teori dan penelitian sebelumnya, maka hipotesis 4 (empat) dinyatakan sebagai berikut:

$\mathrm{H}_{4}$ : Pengalaman auditor memperkuat pengaruh profesionalisme pada kualitas audit.

Menurut Kurnia dkk. (2014) semakin sedikit waktu yang disediakan (time budget pressure yang semakin tinggi), maka semakin besar transkasi yang tidak diuji oleh auditor, dan hal ini akan memengaruhi kualitas audit yang dihasilkan. Penelitian yang telah dilakukan terdahulu mendapatkan hasil yaitu Deviani dan Badera (2017) menemukan bahwa time budget pressure berpengaruh negatif pada kualitas audit. Hasil yang konsisten juga ditemukan oleh Putra dan Mimba (2017). 
Kepuasan kerja auditor sangat erat kaitannya dengan pemenuhan keinginan seorang auditor. Keinginan tersebut diantaranya dapat berupa suasana kerja yang aman dan nyaman, kesejahteraan karyawan yang terjamin, dan fasilitas yang memadai. Kepuasan kerja yang dimiliki oleh seorang auditor dapat memengaruhi sikap dan perilaku auditor ketika menghadapi situasi time budget pressure. Auditor yang sedang menghadapi time budget pressure namun memiliki kepuasan kerja yang tinggi dalam pekerjaanya maka akan tetap mampu menghasilkan kualitas audit yang baik. Salah satu contohnya adalah fasilitas yang memadai di tempat kerja. Auditor yang sedang menghadapi time budget pressure namun fasilitas yang ada di tempat kerja menunjang untuk melaksanakan pekerjaannya, maka auditor tersebut tetap akan mampu menghasilkan kualitas audit yang baik. Hasil penelitian yang dilakukan oleh Purwaningsih dan Suputra (2018) menyatakan bahwa kepuasan kerja mampu memoderasi pengaruh negatif tindakan disfungsional auditor pada kualitas audit. Berdasarkan paparan diatas baik teori dan penelitian sebelumnya, maka hipotesis 5 (lima) adalah sebagai berikut:

$\mathrm{H}_{5}$ : Kepuasan kerja memperlemah pengaruh time budget pressure pada kualitas audit.

Profesional merupakan syarat utama yang harus dimiliki oleh auditor eksternal karena dengan profesionalisme yang tinggi kebebasan auditor akan semakin terjamin dan berdampak pada kualitas auditnya (Agusti dan Pertiwi, 2013). Penelitian yang dilakukan sebelumnya menemukan hasil yaitu Pradipta dan Budiartha (2016) menyatakan bahwa profesionalisme berpengaruh positif pada 
I Gusti Diah Agung Prabawati S. dan Ni Luh Sari Widhiyani. Pengalaman...

kualitas audit. Hasil yang sejalan juga ditemukan oleh Pramesti dan Wiratmaja (2017).

Seorang auditor memiliki kepuasan kerja yang tinggi maka kinerjanya akan meningkat dan prestasinya akan meningkat pula. Kepuasan kerja dapat memengaruhi sikap dan perilaku auditor dalam menjalankan profesinya secara profesional. Seorang auditor yang profesional dan ditambah dengan kepuasan kerja yang dimilikinya maka akan mampu menghasilkan kualitas audit yang baik. Kepuasan kerja dapat menjadi stimulus bagi auditor untuk tetap bekerja maksimal dan sesuai dengan standar profesi akuntan publik sehingga akan mengakibatkan peningkatan kualitas audit. Hasil penelitian yang dilakukan oleh Purwaningsih dan Suputra (2018) menyatakan bahwa kepuasan kerja mampu memoderasi pengaruh positif profesionalisme pada kualitas audit. Berdasarkan paparan diatas baik teori dan penelitian sebelumnya, maka hipotesis 6 (enam) dinyatakan sebagai berikut:

$\mathrm{H}_{6}$ : Kepuasan kerja memperkuat pengaruh profesionalisme pada kualitas audit.

\section{METODE PENELITIAN}

Lokasi dari penelitian ini adalah KAP yang ada di Bali. KAP ini merupakan anggota Institut Akuntan Publik Indonesia dan telah terdaftar dalam direktori Kantor Akuntan Publik Indonesia. Tabel 1 berisi tentang daftar beserta alamat KAP. 
Tabel 1.

Daftar Nama Kantor Akuntan Publik di Bali Tahun 2018

\begin{tabular}{|c|c|c|}
\hline No & Nama Kantor Akuntan Publik & Alamat Kantor Akuntan Publik \\
\hline 1 & KAP I Wayan Ramantha & $\begin{array}{l}\text { Jl. Rampai No. IA Lt. 3, Denpasar, Bali. Telp: } \\
\text { (0361) } 263643\end{array}$ \\
\hline 2 & $\begin{array}{l}\text { KAP Johan Malonda Mustika \& Rekan } \\
\text { (Cab) }\end{array}$ & $\begin{array}{l}\text { Jl. Muding Indah I/5, Kerobokan Utara, } \\
\text { Badung, Bali. Telp: (0361) } 434884\end{array}$ \\
\hline 3 & KAP K. Gunarsa & $\begin{array}{l}\text { Jl. Tukad Banyusari Gg. II No.5, Denpasar, } \\
\text { Bali. Telp: (0361) } 225580\end{array}$ \\
\hline 4 & KAP Drs. I Ketut Budiartha M.Si & $\begin{array}{l}\text { Jl. Gunung Agung Perum Padang Pesona, Graha } \\
\text { Adi A6, Denpasar, Bali. Telp: (0361) } 8849168\end{array}$ \\
\hline 5 & $\begin{array}{l}\text { KAP Drs. Sri Marmo Djogosarkoro \& } \\
\text { Rekan }\end{array}$ & $\begin{array}{l}\text { Jl. Gunung Muria Blok VE No. 4, Monang } \\
\text { Maning, Denpasar, Bali. Telp: (0361) 480033, } \\
\text { 480032, } 482422 \text {. }\end{array}$ \\
\hline 6 & KAP Drs. Wayan Sunasdyana & $\begin{array}{l}\text { Jl. Pura Demak I Gang Buntu No. 89, Denpasar, } \\
\text { Bali. Telp: (0361) 7422329, } 8518989\end{array}$ \\
\hline 7 & $\begin{array}{l}\text { KAP Drs. Ketut Muliartha R.M. \& } \\
\text { Rekan }\end{array}$ & $\begin{array}{l}\text { Jl. Drupadi No.25, Denpasar, Bali. Telp: (0361) } \\
248110,265227 .\end{array}$ \\
\hline 8 & KAP Arnaya \& Darmayasa & $\begin{array}{l}\text { Jl. Cargo Indah III A, Perum Melang Hill No. 1, } \\
\text { Ubung, Denpasar Utara, Denpasar } 80116\end{array}$ \\
\hline 9 & KAP Budhananda Munidewi & $\begin{array}{l}\text { Jl. Tukad Irawadi No. } 18 \text { A, Lantai } 2 \text { \& 3, } \\
\text { Kelurahan Panjer, Kecamatan Denpasar Selatan, } \\
\text { Bali } 80225\end{array}$ \\
\hline
\end{tabular}

Populasi dalam penelitian ini adalah seluruh auditor yang bekerja di KAP

Bali. Rincian jumlah auditor yang bekerja pada KAP di Bali disajikan dalam

Tabel 2.

Tabel 2.

Jumlah Auditor pada Kantor Akuntan Publik di Bali Tahun 2018

\begin{tabular}{llc}
\hline No & \multicolumn{1}{c}{ Nama Kantor Akuntan Publik } & $\begin{array}{c}\text { Jumlah Auditor } \\
\text { (orang) }\end{array}$ \\
\hline 1 & KAP I Wayan Ramantha & 7 \\
2 & KAP Johan Malonda Mustika \& Rekan (Cab) & 10 \\
3 & KAP K. Gunarsa & 12 \\
4 & KAP Drs. I Ketut Budiartha M.Si & 10 \\
5 & KAP Drs. Sri Marmo Djogosarkoro \& Rekan & 17 \\
6 & KAP Drs. Wayan Sunasdyana & 6 \\
7 & KAP Drs. Ketut Muliartha R.M. \& Rekan & 7 \\
8 & KAP Arnaya \& Darmayasa & 2 \\
9 & KAP Budhananda Munidewi & 6 \\
\hline Total & & 77 \\
\hline
\end{tabular}

Sumber: Kantor Akuntan Publik di Bali, 2018

Metode penentuan sampel yang dipilih adalah non probability sampling dengan teknik purposive sampling, yaitu teknik pengambilan sampel dengan kriteria tertentu. Kriteria yang digunakan dalam penentuan sampel pada 
I Gusti Diah Agung Prabawati S. dan Ni Luh Sari Widhiyani. Pengalaman...

penelitian ini yaitu memiliki pengalaman sebagai auditor minimal selama 1 tahun. Kriteria ini dipilih karena seseorang yang memiliki pengalaman sebagai auditor minimal selama 1 tahun dianggap telah memiliki pengalaman yang cukup. Sampel akhir dalam penelitian ini berjumlah 42 responden.

Teknik analisis data yang digunakan dalam penelitian ini adalah Moderated Regression Analysis (MRA). MRA merupakan teknik analisis data yang digunakan untuk mengetahui pengaruh variabel independen pada variabel dependennya dan kemampuan variabel pemoderasi dalam memoderasi pengaruh variabel independen pada variabel dependennya. Model regresi dalam penelitian ini ditunjukkan dengan persamaan sebagai berikut:

$$
\begin{aligned}
& \mathrm{Y}=\alpha+\beta_{1} \mathrm{X}_{1}+\beta_{2} \mathrm{X}_{2}+\beta_{3} \mathrm{M}_{1}+\beta_{4} \mathrm{M}_{2}+\mu \\
& \mathrm{Y}=\alpha+\beta_{1} \mathrm{X}_{1}+\beta_{2} \mathrm{X}_{2}+\beta_{3} \mathrm{M}_{1}+\beta_{4} \mathrm{M}_{2}+\beta_{5} \mathrm{X}_{1} \mathrm{M}_{1}+\beta_{6} \mathrm{X}_{2} \mathrm{M}_{1}+\beta_{7} \mathrm{X}_{1} \mathrm{M}_{2}+ \\
& \beta_{8} \mathrm{X}_{2} \mathrm{M}_{2}+\mu
\end{aligned}
$$

Keterangan:

Y : Kualitas audit

A : Konstanta

$\mathrm{B}_{1}-\beta_{8} \quad:$ Koefisien

$\mathrm{X}_{1} \quad$ : Time Budget Pressure

$\mathrm{X}_{2} \quad$ : Profesionalisme

$\mathrm{M}_{1} \quad$ : Pengalaman Auditor

$\mathrm{M}_{2} \quad$ : Kepuasan Kerja

$\mu \quad$ : Standard Error

\section{HASIL DAN PEMBAHASAN}

Statistik deskriptif menyajikan informasi mengenai karakteristik variabel-variabel penelitian yaitu jumlah amatan, nilai range, nilai median, dan standar deviasi. Untuk mengukur nilai sentral dari distribusi data dapat dilakukan dengan pengukuran rata-rata (mean) sedangkan standar deviasi merupakan perbedaan 
nilai data yang diteliti dengan nilai rata-ratanya. Hasil statistik deskriptif dapat dilihat pada Tabel 3 .

Tabel 3.

Hasil Statistik Deskriptif

\begin{tabular}{lllllc}
\hline \multicolumn{1}{c}{ Variabel } & N & Min. & Max. & Mean & $\begin{array}{c}\text { Std. } \\
\text { Deviasi }\end{array}$ \\
\hline Kualitas Audit & 42 & 26 & 37 & 31,6667 & 2,62880 \\
Time Budget Pressure & 42 & 8 & 16 & 12,2143 & 2,14744 \\
Profesionalisme & 42 & 19 & 28 & 23,5238 & 1,85101 \\
Pengalaman Auditor & 42 & 12 & 16 & 13,2619 & 1,66835 \\
Kepuasan Kerja & 42 & 21 & 30 & 25,3095 & 1,98148 \\
\hline Sumber: Data diolah, 2018 & & & &
\end{tabular}

Berdasarkan Tabel 3 dapat dijelaskan bahwa kualitas audit (Y) memiliki nilai minimum sebesar 26 dan nilai maksimum sebesar 37 , dengan rata-rata sebesar 31,6667. Nilai rata-rata sebesar 31,6667 menunjukkan bahwa respon responden dalam menjawab pernyatan pada kuesioner cenderung merasa setuju pada masing-masing item pernyataan. Nilai standar deviasi adalah sebesar 2,62880. Ini berarti bahwa terjadi perbedaan nilai kualitas audit yang diteliti terhadap nilai rata-ratanya sebesar 2,62880.

Time budget pressure $\left(\mathrm{X}_{1}\right)$ memiliki nilai minimum sebesar 8 dan nilai maksimum sebesar 16 , dengan rata-rata sebesar 12,2143 . Nilai rata-rata sebesar 12,2143 menunjukkan bahwa respon responden dalam menjawab pernyataan pada kuesioner cenderung merasa setuju pada masing-masing item pernyataan. Nilai standar deviasi adalah sebesar 2,14744. Ini berarti bahwa terjadi perbedaan nilai time budget pressure yang diteliti terhadap nilai rata-ratanya sebesar 2,14744.

Profesionalisme $\left(\mathrm{X}_{2}\right)$ memiliki nilai minimum sebesar 19 dan nilai maksimum sebesar 28, dengan rata-rata sebesar 23,5238. Nilai rata-rata sebesar 23,5238 menunjukkan bahwa respon responden dalam menjawab pernyataan pada kuesioner cenderung merasa setuju pada masing-masing item pernyataan. Nilai 
I Gusti Diah Agung Prabawati S. dan Ni Luh Sari Widhiyani. Pengalaman...

standar deviasi adalah sebesar 1,85101. Ini berarti bahwa terjadi perbedaan nilai profesionalisme yang diteliti terhadap nilai rata-ratanya sebesar 1,85101 .

Pengalaman auditor $\left(\mathrm{M}_{1}\right)$ memiliki nilai minimum sebesar 12 dan nilai maksimum sebesar 16, dengan rata-rata sebesar 13,2619. Nilai rata-rata sebesar 13,2619 menunjukkan bahwa respon responden dalam menjawab pernytaan pada kuesioner cenderung merasa setuju pada masing-masing item pernyataan. Nilai standar deviasi adalah sebesar 1,66835. Ini berarti bahwa terjadi perbedaan nilai pengalaman auditor yang diteliti terhadap nilai rata-ratanya sebesar 1,66835.

Kepuasan kerja $\left(\mathrm{M}_{2}\right)$ memiliki nilai minimum sebesar 21 dan nilai maksimum sebesar 30, dengan rata-rata sebesar 25,3095. Nilai rata-rata sebesar 25,3095 menunjukkan bahwa respon responden dalam menjawab pernyataan pada kuesioner cenderung merasa setuju pada masing-masing item pernyataan. Nilai standar deviasi adalah sebesar 1,98148. Ini berarti bahwa terjadi perbedaan nilai kepuasan kerja yang diteliti terhadap nilai rata-ratanya sebesar 1,98148.

Teknik perhitungan dan analisis data menggunakan Moderated Regression Analysis. Hasil pengujian disajikan pada Tabel 5.

Tabel 5.

Hasil Analisis Regresi Moderasi

\begin{tabular}{|c|c|c|c|c|c|}
\hline \multirow[t]{2}{*}{ Model } & \multicolumn{2}{|c|}{$\begin{array}{c}\text { Unstandardized } \\
\text { Coefficients }\end{array}$} & \multirow{2}{*}{$\begin{array}{c}\text { Standardized } \\
\text { Coefficients } \\
\text { Beta } \\
\end{array}$} & \multirow[b]{2}{*}{$\mathbf{t}$} & \multirow[b]{2}{*}{ Sig. } \\
\hline & B & Std. Error & & & \\
\hline $\begin{array}{ll}1 & \text { (Constant) }\end{array}$ & .018 & .121 & & .146 & .885 \\
\hline Time Budget Pressure & -.720 & .271 & -.720 & -2.662 & .012 \\
\hline Profesionalisme & .641 & .256 & .641 & 2.503 & .017 \\
\hline Pengalaman Auditor & .209 & .252 & .209 & .829 & .413 \\
\hline Kepuasan Kerja & .195 & .192 & .206 & 1.012 & .319 \\
\hline X1.M1 & .668 & .279 & .682 & 2.390 & .023 \\
\hline X2.M1 & .566 & .214 & .512 & 2.643 & .012 \\
\hline $\mathrm{X} 1 . \mathrm{M} 2$ & .527 & .255 & .527 & 2.063 & .047 \\
\hline $\mathrm{X} 2 . \mathrm{M} 2$ & .804 & .312 & .852 & 2.577 & .015 \\
\hline R Square & & & & & 0,570 \\
\hline
\end{tabular}




\begin{tabular}{|c|c|c|c|c|c|c|}
\hline \multirow{2}{*}{\multicolumn{2}{|c|}{ Model }} & \multicolumn{2}{|c|}{$\begin{array}{l}\text { Unstandardized } \\
\text { Coefficients }\end{array}$} & \multirow{2}{*}{$\begin{array}{c}\text { Standardize } \\
\text { Coefficients } \\
\text { Beta } \\
\end{array}$} & \multirow[b]{2}{*}{$\mathbf{t}$} & \multirow[b]{2}{*}{ Sig. } \\
\hline & & B & Std. Error & & & \\
\hline \multirow[t]{8}{*}{1} & (Constant) & .018 & .121 & & .146 & .885 \\
\hline & Time Budget Pressure & -.720 & .271 & -.720 & -2.662 & .012 \\
\hline & Profesionalisme & .641 & .256 & .641 & 2.503 & .017 \\
\hline & Pengalaman Auditor & .209 & .252 & .209 & .829 & .413 \\
\hline & Kepuasan Kerja & .195 & .192 & .206 & 1.012 & .319 \\
\hline & X1.M1 & .668 & .279 & .682 & 2.390 & .023 \\
\hline & X2.M1 & .566 & .214 & .512 & 2.643 & .012 \\
\hline & X1.M2 & .527 & .255 & .527 & 2.063 & .047 \\
\hline & $\mathrm{X} 2 . \mathrm{M} 2$ & .804 & .312 & .852 & 2.577 & .015 \\
\hline \multicolumn{4}{|c|}{ Adjusted R Square } & & & 0,466 \\
\hline \multicolumn{4}{|c|}{ F Statistik } & & & 5,472 \\
\hline \multicolumn{4}{|c|}{ Signifikansi } & & & 0,000 \\
\hline
\end{tabular}

Berdasarkan Tabel 5 dapat disusun persamaan regresi sebagai berikut:

$$
\begin{aligned}
Y= & 0,018-0,720 X_{1}+0,641 X_{2}+0,209 M_{1}+0,195 M_{2}+0,668 X_{1} M_{1}+ \\
& 0,566 X_{2} M_{1}+0,527 X_{1} M_{2}+0,804 X_{2} M_{2}+\mu
\end{aligned}
$$

Nilai konstanta sebesar 0,018 menunjukkan bahwa apabila nilai time budget pressure $\left(\mathrm{X}_{1}\right)$, profesionalisme $\left(\mathrm{X}_{2}\right)$, pengalaman auditor $\left(\mathrm{M}_{1}\right)$, dan kepuasan kerja $\left(\mathrm{M}_{2}\right)$ sama dengan nol, maka kualitas audit adalah sebesar 0,018. Nilai koefisien $\beta_{1}=-0,720$. Hal ini bermakna bahwa apabila time budget pressure semakin meningkat, maka kualitas audit akan semakin menurun. Nilai koefisien $\beta_{2}=$ 0,641. Hal ini bermakna bahwa apabila profesionalisme semakin meningkat, maka kualitas audit akan semakin meningkat. Nilai koefisien $\beta_{3}=0,209$. Hal ini bermakna bahwa apabila pengalaman auditor semakin meningkat, maka kualitas audit akan semakin meningkat. Nilai koefisien $\beta_{4}=0,195$. Hal ini bermakna bahwa apabila kepuasan kerja semakin meningkat, maka kualitas audit akan semakin meningkat. Nilai koefisien $\beta_{5}=0,668$. Hal ini bermakna bahwa setiap interaksi time budget pressure dengan pengalaman auditor semakin meningkat, maka kualitas audit akan semakin meningkat. Nilai koefisien $\beta_{6}=0,566$. Hal ini 
I Gusti Diah Agung Prabawati S. dan Ni Luh Sari Widhiyani. Pengalaman...

bermakna bahwa setiap interaksi profesionalisme dengan pengalaman auditor semakin meningkat, maka kualitas audit akan semakin meningkat. Nilai koefisien $\beta_{7}=0,527$. Hal ini bermakna bahwa setiap interaksi time budget pressure dengan kepuasan kerja semakin meningkat, maka kualitas audit akan semakin meningkat. Nilai koefisien $\beta_{8}=0,804$. Hal ini bermakna bahwa setiap interaksi profesionalisme dengan kepuasan kerja semakin meningkat, maka kualitas audit akan semakin meningkat.

Berdasarkan hasil analisis regresi moderasi yang pada Tabel 5, besanya nilai signifikansi $\mathrm{P}$ value 0,000 yang lebih kecil dari $\alpha=0,05$. Hal ini berarti bahwa model yang digunakan pada penelitian ini adalah layak. Hasil ini memberikan makna bahwa seluruh variabel independen mampu memprediksi atau menjelaskan fenomena kualita audit. Time budget pressure $\left(\mathrm{X}_{1}\right)$, profesionalisme $\left(\mathrm{X}_{2}\right)$, pengalaman auditor $\left(M_{1}\right)$, kepuasan kerja $\left(M_{2}\right)$, interaksi $X_{1} \cdot M_{1}$, interaksi $X_{2} \cdot M_{1}$, interaksi $\mathrm{X}_{1} \cdot \mathrm{M}_{2}$, dan interaksi $\mathrm{X}_{2} \cdot \mathrm{M}_{2}$ secra simultan berpengaruh signifikan terhadap kualitas audit. Hal ini berarti bahwa model dapat digunakan untuk analisa lebih lanjut.

Koefisien determinasi $\left(\mathrm{R}^{2}\right)$ digunakan untuk mengetahui dan mengukur kemampuan model dalam menerangkan variasi variabel independen. Peneliti menggunakan nilai adjusted $\mathrm{R}^{2}$ pada penelitian ini. Hal ini karena nilai adjusted $\mathrm{R}^{2}$ dapat naik atau turun apabila satu variabel independen ditambahkan ke dalam model. Hasil uji memberikan hasil besarnya adjusted $\mathrm{R}^{2}$ (koefisien determinasi yang telah disesuaikan) pada Tabel 4.10 adalah 0,466 . Hal ini berati variasi kualitas audit dapat dipengaruhi secara signifikan oleh variabel time budget 
pressure $\left(\mathrm{X}_{1}\right)$, profesionalisme $\left(\mathrm{X}_{2}\right)$, pengalaman auditor $\left(\mathrm{M}_{1}\right)$, kepuasan kerja $\left(\mathrm{M}_{2}\right)$, interaksi $\mathrm{X}_{1} \cdot \mathrm{M}_{1}$, interaksi $\mathrm{X}_{2} \cdot \mathrm{M}_{1}$, interaksi $\mathrm{X}_{1} \cdot \mathrm{M}_{2}$, dan interaksi $\mathrm{X}_{2} \cdot \mathrm{M}_{2}$ sebesar $46,6 \%$, sedangkan sisanya sebesar $53,4 \%$ dijelaskan oleh faktor-faktor lain yang tidak dijelaskan dalam model penelitian.

Uji $\mathrm{t}$ digunakan untuk mengetahui pengaruh masing-masing variabel independen secara parsial terhadap variabel dependen dan untuk mengetahui apakah variabel pemoderasi mampu memoderasi pengaruh variabel dependen terhadap variabel dependennya. Berdasarkan Tabel 5 maka hasil uji t dapat diartikan sebagai berikut:

Berdasarkan hasil analisis pengaruh time budget pressure pada kualitas audit diperoleh nilai signifikansi sebesar 0,012 lebih kecil dari 0,05 dengan nilai koefisien regresi sebesar $-0,720$. Hasil ini mempunyai arti bahwa time budget pressure berpengaruh negatif dan signifikan pada kualitas audit.

Hasil ini membuktikan bahwa tekanan yang diakibatkan oleh anggaran waktu yang sempit yang dialami auditor pada KAP di Bali menyebabkan penurunan kualitas audit yang dihasilkannya. Berdasarkan penemuan tersebut, dapat digambarkan bahwa time budget pressure memiliki peran dalam menentukan kualitas audit yang dihasilkan oleh auditor di KAP di Bali. Coram et al. (2003) menemukan bahwa menurunnya kualitas audit dikarenakan anggaran waktu yang ketat. Anggaran waktu yang ketat mengakibabtkan beban kerja yang dihadapi oleh auditor menjadi tinggi. Anggaran waktu yang ketat akan melahirkan tekanan yang berat bagi auditor dalam menjalankan prosedur auditnya sehingga berdampak pada kualitas audit yang dihasilkan. Temuan ini sejalan dengan 
I Gusti Diah Agung Prabawati S. dan Ni Luh Sari Widhiyani. Pengalaman...

penelitian yang dilakukan oleh Broberg et al. (2016) yang menemukan bahwa time budget pressure menurunkan kualitas audit yang dihasilkan auditor. Penelitian Kurnia dkk. (2014), Santhi dan Ratnadi (2017), Putra (2013), dan Nirmala dan Caryonowati (2013) juga menemukan pengaruh negatif time budget pressure pada kualitas audit.

Berdasarkan hasil analisis pengaruh profesionalisme pada kualitas audit diperoleh nilai signifikansi sebesar 0,017 lebih kecil dari 0,05 dengan nilai koefisien regresi sebesar 0,641. Hasil ini mempunyai arti bahwa profesionalisme berpengaruh positif dan signifikan pada kualitas audit.

Hasil ini membuktikan bahwa sikap profesionalisme yang dimiliki oleh auditor pada KAP di Bali meningkatkan kualitas audit yang dihasilkan. Berdasarkan penemuan tersebut, dapat digambarkan bahwa profesionalisme memiliki peran dalam menentukan kualitas audit yang dihasilkan oleh auditor pada KAP di Bali.

Menurut Futri dan Juliarsa (2014) seorang auditor yang profesional artinya adalah bertanggung jawab dan berperilaku lebih baik dari sekedar mematuhi undang-undang, kode etik, dan peraturan yang ada. Sikap profesionalisme yang tinggi akan mengakibatkan peningkatan kualitas audit yang dihasilkan, karena auditor akan selalu bertindak sesuai dengan standar yang telah ditetapkan. Temuan ini sejalan dengan penelitian yang dilakukan oleh Fitria (2016) yang menemukan bahwa profesionalisme berpengaruh positif pada kualitas audit. Penelitian Agusti dan Pertiwi (2013), Lesmana dan Machdar (2015), 
Purwaningsih dan Suputra (2018), Dewi dan Muliartha (2018) juga menemukan pengaruh positif profesionalisme pada kualitas audit.

Hasil analisis regresi moderasi menunjukkan bahwa nilai keofisien regresi time budget pressure $\left(\beta_{1}\right)$ negatif sebesar $-0,720$ dengan nilai signifikansi sebesar 0,012 dan nilai koefisien regresi variabel interaksi $X_{1} \cdot M_{1}\left(\beta_{5}\right)$ positif sebesar 0,668 dengan nilai signifikansi 0,023 , maka hal tersebut menunjukkan adanya hubungan yang berlawanan karena memiliki nilai koefisien yang berbeda. Berdasarkan hal tersebut, dapat disimpulkan bahwa variabel pengalaman auditor merupakan variabel moderasi yang memperlemah pengaruh time budget pressure pada kualitas audit.

Temuan ini sejalan dengan hasil penelitian yang dilakukan oleh Nurhayati (2015) dan Hutabarat (2012) yang menemukan bahwa pengalaman auditor berpengaruh positif pada kualitas audit. Hasil ini membuktikan bahwa pengalaman yang dimiliki auditor pada KAP di Bali mampu memperlemah pengaruh dari tekanan yang timbul akibat keterbatasan waktu yang tersedia yang memengaruhi kualitas audit yang dihasilkan. Berdasarkan penemuan tersebut, dapat digambarkan bahwa pengalaman yang dimiliki auditor memiliki peran dalam menentukan kualitas audit yang dihasilkan oleh auditor pada KAP di Bali, terutama dalam kaitannya untuk memperlemah pengaruh yang ditimbulkan time budget pressure pada kualitas audit.

Hasil analisis regresi moderasi menunjukkan bahwa nilai koefisien regresi profesionalisme $\left(\beta_{2}\right)$ positif sebesar 0,641 dengan nilai signifikansi sebesar 0,017 dan nilai koefisien regresi variabel interaksi $X_{2} \cdot M_{1}\left(\beta_{6}\right)$ positif sebesar 0,566 
I Gusti Diah Agung Prabawati S. dan Ni Luh Sari Widhiyani. Pengalaman...

dengan nilai signifikansi 0,012, maka hal tersebut menunjukkan adanya hubungan yang searah karena sama-sama memiliki nilai koefisien yang positif. Berdasarkan hal tersebut, dapat disimpulkan bahwa variabel pengalaman auditor merupakan variabel moderasi yang memperkuat pengaruh profesionalisme pada kualitas audit.

Temuan ini sejalan dengan penelitian yang dilakukan oleh Dewi dan Sudana (2018) dan Wulandari dan Wirakusuma (2017) yang menemukan bahwa pengalaman auditor berpengaruh positif pada kualitas audit. Berdasarkan penemuan tersebut, dapat digambarkan bahwa pengalaman yang dimiliki auditor memiliki peran dalam menentukan kualitas audit yang dihasilkan oleh auditor pada KAP di Bali, terutama dalam kaitannya untuk memperkuat pengaruh yang ditimbulkan profesionalisme pada kualitas audit.

Fenomena yang ditunjukkan oleh penelitian ini mengindikasikan bahwa semakin tinggi profesionalisme yang dimiliki oleh seorang auditor dapat meningkatkan kualitas audit yang dihasilkan. Pengalaman auditor memberikan pengaruh positif dalam meningkatkan kualitas audit. Auditor yang berpengalaman memiliki kompetensi dan pengetahuan yang lebih dibandingan dengan auditor yang belum berpengalaman, sehingga dalam melaksanakan prosedur audit akan lebih cermat, teliti, dan memahami segala jenis peraturan yang berkaitan dengan audit. Seorang auditor yang profesional dan ditambah dengan pengalaman yang dimiliki maka akan membuat kualitas audit yang dihasilkannya semakin baik.

Hasil analisis regresi moderasi menunjukkan bahwa nilai koefisien regresi time budget pressure $\left(\beta_{1}\right)$ negatif sebesar $-0,720$ dengan nilai signifikansi sebesar 
0,012 dan nilai koefisien regresi variabel interaksi $X_{1} \cdot M_{2}\left(\beta_{7}\right)$ positif sebesar 0,527 dengan nilai signifikansi 0,047, maka hal tersebut menunjukkan adanya hubungan yang berlawanan karena memiliki nilai koefisien yang berbeda. Berdasarkan hal tersebut, dapat disimpulkan bahwa variabel kepuasan kerja merupakan variabel moderasi yang memperlemah pengaruh time budget pressure pada kualitas audit.

Fenomena yang ditunjukkan oleh penelitian ini mengindikasikan bahwa semakin tinggi time budget pressure yang dialami oleh seorang auditor dapat menurunkan kualitas audit yang dihasilkan. Kepuasan kerja memberikan pengaruh positif dalam meningkatkan kualitas audit. Kepuasan kerja memiliki hubungan dengan pemenuhan keinginan auditor di tempat kerja. Keinginan tersebut diantaranya dapat berupa suasana kerja yang aman dan nyaman, kesejahteraan karyawan yang terjamin, dan fasilitas yang memadai. Auditor yang menghadapi time budget pressure namum memiliki kepuasan kerja yang tinggi dalam pekerjaannya maka akan mampu menghasilkan kualitas audit yang baik. Hal ini berkaitan dengan kepuasan kerja dapat menjadi stimulus bagi auditor untuk tetap menghasilkan kualitas audit yang baik walaupun sedang menghadapi time budget pressure.

Hasil analisis regresi moderasi menunjukkan bahwa nilai koefisien regresi profesionalisme $\left(\beta_{2}\right)$ positif sebesar 0,641 dengan nilai signifikansi sebesar 0,017 dan nilai koefisien regresi variabel interaksi $\mathrm{X}_{2} \cdot \mathrm{M}_{2}\left(\beta_{8}\right)$ positif sebesar 0,804 dengan nilai signifikansi 0,015 , maka hal tersebut menunjukkan adanya hubungan yang searah karena sama-sama memiliki nilai koefisien yang positif. Berdasarkan hal tersebut, dapat disimpulkan bahwa variabel kepuasan kerja merupakan 
I Gusti Diah Agung Prabawati S. dan Ni Luh Sari Widhiyani. Pengalaman...

variabel moderasi yang memperkuat pengaruh profesionalisme pada kualitas audit.

Temuan ini sejalan dengan hasil penelitian yang dilakukan oleh Pelawati dkk. (2018) yang menemukan bahwa kepuasan kerja berpengaruh positif pada kualitas audit. Hasil ini membuktikan bahwa kepuasan kerja yang dimiliki auditor pada KAP di Bali mampu memperkuat pengaruh profesionalisme pada kualitas audit yang dihasilkan. Berdasarkan penemuan tersebut, dapat digambarkan bahwa kepuasan kerja yang dimiliki auditor memiliki peran dalam menentukan kualitas audit yang dihasilkan oleh auditor pada KAP di Bali, terutama dalam kaitannya untuk memperkuat pengaruh yang ditimbulkan profesionalisme pada kualitas audit.

Fenomena yang ditunjukkan oleh penelitian ini mengindikasikan bahwa semakin tinggi profesionalisme yang dimiliki auditor dapat meningkatkan kualitas audit yang dihasilkan. Kepuasan kerja memberikan pengaruh positif dalam meningkatkan kualitas audit. Kepuasan kerja yang erat kaitannya dengan pemenuhan keinginan di tempat kerja dapat memengaruhi sikap dan perilaku auditor dalam menjalankan profesinya secara professional. Seorang auditor yang memiliki sikap profesional yang tinggi dan ditambah dengan kepuasan kerja yang dimilikinya maka akan menghasilkan kualitas audit yang baik.

\section{SIMPULAN}

Berdasarkan hasil pengujian dan pembahasan pada bab sebelumnya dapat disimpulkan bahwa Time budget pressure berpengaruh negatif pada kualitas audit 
di KAP di Bali. Hal ini berati bahwa semakin tinggi time budget pressure yang dialami oleh seorang auditor, maka akan semakin menurun kualitas audit yang dihasilkan.

Profesionalisme berpengaruh positif pada kualitas audit di KAP di Bali. Hal ini berati bahwa semakin tinggi sikap profesionalisme yang dimiliki oleh seorang auditor, maka akan semakin meningkat kualitas audit yang dihasilkan.

Pengalaman auditor memoderasi pengaruh negatif time budget pressure pada kualitas audit di KAP di Bali. Pengalaman auditor memperlemah pengaruh time budget pressure pada kualitas audit. Hal ini berati bahwa seorang auditor yang sedang mengalami time budget pressure namun berpengalaman akan tetap mampu menghasilkan kualitas audit yang baik.

Pengalaman auditor memoderasi pengaruh positif profesionalisme pada kualitas audit di KAP di Bali. Pengalaman auditor memperkuat pengaruh profesionalisme pada kualitas audit. Hal ini berati bahwa seorang auditor yang memiliki sikap profesionalisme dan ditambah dengan pengalaman yang dimilikinya akan menghasilkan kualitas audit yang semakin baik.

Kepuasan kerja memoderasi pengaruh negatif time budget pressure pada kualitas audit di KAP di Bali. Kepuasan kerja memperlemah pengaruh time budget pressure pada kualitas audit. Hal ini berati bahwa seorang auditor yang sedang mengalami time budget pressure namun memiliki kepuasan kerja dalam pekerjaannya akan tetap mampu menghasilkan kualitas audit yang baik.

Kepuasan kerja memoderasi pengaruh positif profesionalisme yang pada kualitas audit di KAP di Bali. Kepuasan kerja memperkuat pengaruh 
I Gusti Diah Agung Prabawati S. dan Ni Luh Sari Widhiyani. Pengalaman...

profesionalisme pada kualitas audit. Hal ini berati bahwa seorang auditor yang memiliki sikap profesionalisme dan ditambah dengan kepuasan kerja yang dimilikinya akan menghasilkan kualitas audit yang semakin baik.

Berdasarkan simpulan, maka saran yang dapat disampaikan adalah hasil kuesioner variabel time budget pressure pada indikator waktu penugasan yang terbatas, auditor yang bekerja di KAP di Bali sebaiknya lebih memanfaatkan waktu yang tersedia sehingga mampu memenuhi taget pekerjaan. Hasil kuesioner variabel profesionalisme pada indikator keyakinan terhadap peraturan profesi, auditor yang bekerja di KAP di Bali sebaiknya lebih berpengang teguh pada peraturan profesinya sehingga selalu menjalankan tugasnya sesuai dengan peraturan yang berlaku.

Peneliti selanjutnya dapat menerapkan di lokasi penelitian yang lain seperti BUMN, pemerintahan, dan lainnya. Penelitian ini menggunakan seluruh auditor sebagai sampel hanya dengan melihat pengalaman auditor yang dimiliki dan tidak dibatasi oleh jabatan, penelitian selanjutnya dapat mengembangkan penelitian dengan menjadikan auditor di level senior, manajer, dan partner sebagai sampel karena pada level inilah kualitas audit ditentukan. Penelitian ini hanya menggunakan teknik analisis moderasi (MRA), penelitian selanjutnya dapat mengembangkan dengan menggunakan teknik analisis yang lainnya, seperti: konfirmatori, SEM Analysis dan Path Analysis. 


\section{REFERENSI}

Agusti, Restu and Nastia Putri Pertiwi. 2013. "Pengaruh Kompetensi, Independensi Dan Profesionalisme Terhadap Kualitas Audit (Studi Empiris Pada Kantor Akuntan Publik Se Sumatera).” Jurnal Ekonomi 21(3):1-13.

Anggreni, Ni Wayan Dewi and Ni Ketut Rasmini. 2017. "Pengaruh Pengalaman Auditor Dan Time Budget Pressure Pada Profesionalisme Dan Implikasinya Terhadap Kinerja Auditor." E-Jurnal Akuntansi Universitas Udayana 18(1):145-75.

Annisa, Natasha Rizky and Made Gede Wirakusuma. 2016. "Pengalaman Kerja Sebagai Pemoderasi Pengaruh Due Professional Care Pada Kaulitas Audit." E-Jurnal Akuntansi Universitas Udayana 17(1):1-28.

Arisinta, Octaviana. 2013. "Pengaruh Kompetensi, Independensi, Time Budget Pressure, Dan Audit Fee Terhadap Kualitas Audit Pada Kantor Akuntan Publik Di Surabaya." Jurnal Ekonomi Dan Bisnis 23(3):266-78.

Barrainkua, Itsaso and Marcela Espinosa-Pike. 2018. "The Influence of Auditors' Professionalism on Ethical Judgement: Differences Among Practitioners and Postgraduate Students." Revista de Contabilidad 21(2):176-87.

Bisnistempo. 2017. "Mitra Ernst \& Young Indonesia Di Denda Rp 13 Miliar Di AS.” Retrieved (https://bisnis.tempo.co/read/845604/mitra-ernst-youngindonesia-didenda-rp-13-miliar-di-as).

Broberg, Pernilla et al. 2017. "Explaining The Influence of Time Budget Pressure on Audit Quality in Sweden." Journal of Management and Governance 21(2):331-50.

Coram, Paul, Juliana Ng, and David Woodliff. 2003. "A Survey of Time Budget Pressure and Reduced Audit Quality Among Australian Auditors.” Australia Accounting Review 13(1):38-44.

DeAngelo, Linda Elizabeth. 1981. "Auditor Independence, 'Low Balling', and Disclosure Regulation.” Journal of Accounting and Economics 3(2):113-27.

Deviani, Trisna and I. Dewa Nyoman Badera. 2017. "Sistem Informasi Sebagai Pemoderasi Pengaruh Kompleksitas Audit Dan Time Budget Pressure Terhadap Kualitas Audit." E-Jurnal Akuntansi Universitas Udayana 18(2):1171-1201.

Dewi, Luh Ayu Agustina Trisna and Ketut Muliartha. 2018. "Pengaruh Profesionalisme, Integritas, Locus of Control Dan Kinerja Auditor Pada Kualitas Audit.” E-Jurnal Akuntansi Universitas Udayana 23(3):2061-89. 
Dewi, Ni Made Widia Iswara and I. Putu Sudana. 2018. "Pengaruh Pengalaman, Due Professional Care Dan Akuntabilitas Auditor Pada Kualitas Audit." EJurnal Akuntansi Universitas Udayana 22(1):438-63.

Fitria, Marisa. 2016. "Pengaruh Time Budget Pressure, Due Professional Care Dan Etika Auditor Terhadap Kualitas Audit Dengan Perilaku Disfungsional Auditor Sebagai Moderator.” Jurnal, JOM F-KOM 3(1):119-32.

Futri, Putu Septiani and Gede Juliarsa. 2014. "Pengaruh Independensi, Profesionalisme,Tingkat Pendidikan, Etika Profesi, Pengalaman, Dan Kepuasan Kerja Auditor Pada Kualitas Audit Kantor Akuntan Publik Di Bali." E-Jurnal Akuntansi Universitas Udayana 7(2):444-61.

Govindarajan, Vijay. 1986. "Impact of Participation in the Budgetary Process on Managerial Attitudes and Performance: Universalistic and Contingency Perspectives." Decision Sciences 17(4):496-516.

Hanjani, Andreani and Rahardja. 2014. "Pengaruh Etika Auditor, Pengalaman Auditor, Fee Audit, Dan Motivasi Audit Terhadap Kualitas Audit (Studi Pada Auditor KAP Di Semarang)." Diponegoro Journal of Accounting 3(2):111-19.

Herda, David N. and Kasey A. Martin. 2016. "The Effects of Auditor Experience and Professinal Commitment on Accptance of Underreporting Time: A Moderated Mediation Analysis.” Americal Accounting Association 10(2):128.

Heyrani, Forough, Bahman Banimahd, and Fereydoun Rahnamayeh Roudposhti. 2016. "Investigation of the Effect of Auditors' Professionalism Levels on Their Judgment to Resolve the Conflict between Auditor and Management." Procedia Economics and Finance 36(16):177-88. Retrieved (http://linkinghub.elsevier.com/retrieve/pii/S2212567116300296).

Hutabarat, Goodman. 2012. "Pengaruh Pengalaman Time Budget Pressure Dan Etika Auditor Terhadap Kualitas Audit.” Jurnal Ilmiah ESAI 6(1978).

Indrajaya, A. A. Ngurah, Bagus Ida Putra Astika, and Ni Putu Sri Harta Mimba. 2017. "Pengaruh Intellegence Quotient, Emotional Quotient , Spiritual Quotient, Dan Time Budget Pressure Pada Perilaku Underreporting of Time." Jurnal Ilmiah Akuntansi Dan Bisnis 12(2):2302-2514.

Iskandar, Melody and Stefani Lily Indarto. 2014. "Interaksi Independensi, Pengalaman, Pengetahuan, Due Professional Cara, Akuntabilitas Dan Kepuasan Kerja Terhadap Kualitas Audit." 3rd Economics \& Business Research Festival 13 Novembe:1-15. 
Jelista, Mutiara. 2015. "Pengaruh Kompleksitas Audit, Tekanan Anggaran Waktu, Dan Pengalaman AuditorTerhadap Kualitas Audit Dengan Variabel Moderating Sistem Informasi (Studi Empiris Pada Kantor Akuntan Publik Di Pekanbaru, Medan, Dan Padang)." Jom FEKON 2(2):1-15.

Kristianto, Oktavianus and Suwardi Bambang Hermanto. 2017. "Pengaruh Profesionalisme Auditor, Independensi Auditor, Dan Kompetensi Auditor Terhadap Kualitas.” Jurnal Ilmu Dan Riset Akuntansi 6(11):1-19.

Kuntari, Yeni, Anis Chariri, and Nurdhiana. 2017. "The Effect of Auditor Ethics, Auditpr Experience, Audit Fees and Auditor Motivation on Audit Quality." Sriwijawa International Jpurnal Of Dynamic Economics and Business 1(2):203-18.

Retrieved (http://linkinghub.elsevier.com/retrieve/pii/S1645991117300105).

Kurnia, Winda, Khomsiyah, and Sofie. 2014. "Pengaruh Kompetensi, Independensi, Tekanan Waktu, Dan Etika Auditor Terhadap Kualitas Audit.” E-Journal Akuntansi Fakultas Ekonomi 1(2):49-67.

Lesmana, Rudi and Nera Marinda Machdar. 2015. "Pengaruh Profesionalisme, Kompetensi, Dan Independensi Auditor Terhadap Kualitas Audit." Jurnal Bisnis Dan Komunikasi 2(1):33-40.

Libby, Robert and David M. Frederick. 1990. "Experience and the Ability to Explain Audit Findings.” Journal of Accounting Research 28(2):348-67.

Luthans, F. 2015. Organizational Behavior. Newyork: Mc. Graw Hill Book Company.

Mangiwa, Christian et al. 2017. "No TitleThe Effect of Locus of Control, Time Budget Pressure, and Professional Commitment on Dysfunctional Audit Behaviour." Jorunal of Education and Vocational Research 8(2):49-61.

Maryani, T. and U. Ludigdo. 2001. "Survey Atas Faktor-Faktor Yang Mempengaruhi Sikap Dan Perilaku Etis Akuntan.” TEMA 2(1):49-62.

Ningsih, A. .. Putu Ratih Cahaya and P. Dyan Yaniartha. 2013. "Pengaruh Kompetensi, Independensi, Dan Time Budget Pressure Terhadap Kualitas Audit." E-Jurnal Akuntansi Universitas Udayana 4(1):92-109.

Nirmala, Rr Putri Arsika and Nur Caryonowati. 2013. "Pengaruh Independensi, Pengalaman, Due Professional Care, Akuntabilitas, Kompleksitas Audit, Dan Time Budget Pressure Terhadap Kualitas Audit (Studi Empiris Pada Auditor KAP Di Jawa Tengah Dan DIY)." Diponegoro Journal of Accounting 2(3):2337-3806. Retrieved (http://ejournals1.undip.ac.id/index.php/accounting). 
Nurhayati, Enung. 2015. "Pengaruh Pengalaman , Independensi , Dan Time Budget Pressure Terhadap Kualitas Audit Dengan Etika.” JRKA 1(2):16-27.

Pelawati, Anik Malikah, and Junaidi. 2018. "Pengaruh Independensi, Profesionalisme, Tingkat Pendidikan, Etika Profesi, Pengalaman Dan Kepuasan Kerja Auditor Terhadap Kualitas Audit Kantor Akuntan Publik Di Malang.” E-JRA 07(09):51-64.

Pradipta, Gede and I. Ketut Budiartha. 2016. "Tekanan Anggaran Waktu Sebagai Pemoderasi Pengaruh Profesionalisme Dan Pengalaman Audit Pada Kualitas Audit." E-Jurnal Akuntansi Universitas Udayana 15(3):1740-66.

Pramesti, I. Gusti Ayu Rahma and I. Dewa Nyoman Wiratmaja. 2017. "Pengaruh Fee Audit, Profesionalisme Pada Kualitas Audit Dengan Kepuasan Kerja Sebagai Variabel Pemediasi." E-Jurnal Akuntansi Universitas Udayana 18(1):616-45.

Purwaningsih, Putu Ayu Velia and I. D. G. Dharma Suputra. 2018. "Pengaruh Profesionalisme Dan Perilaku Disfungsional Auditor Pada Kualitas Audit Dengan Kepuasan Kerja Sebagai Variabel Moderasi." E-Jurnal Akuntansi Universitas Udayana 24(1):224-52.

Putra, I. Gede Cahyadi. 2013. "Kualitas Audit Kantor Akuntan Publik Di Baditinjau Dari Time Budget Pressure, Risiko Kesalahan, Dan Kompleksitas Audit." Jurnal Ilmiah Akuntansi Dan Humanika 2(2):765-84.

Putra, I. Gede Karma Yudha Permana and Ni Putu Sri Harta Mimba. 2017. "Pengaruh Locus Control, Pengalaman Kerja, Time Budget Pressure Dan Motivasi Auditor Pada Kualitas Audit." E-Jurnal Akuntansi Universitas Udayana 18(2):1286-1313.

Riyandari, Putu Karina and I. Dewa Nyoman Badera. 2017. "Pengalaman Auditor Sebagai Pemoderasi Pengaruh Time Budget Pressure Dan Kompleksitas Audit Pada Kualitas Audit." E-Jurnal Akuntansi Universitas Udayana 19(1):195-222.

Santhi, Luh Gde Merta Widya and Ni Made Dwi Ratnadi. 2017. "Independensi Auditor Sebagai Pemediasi Pengaruh Fee Audit Dan Time Budget Pressure Pada Kualitas Audit." E-Jurnal Akuntansi UNiversitas Udayana 19(3):205989.

Surtikanti and Lena Lestary. 2012. "Pengaruh Profesionalisme Akuntan Publik Dan Perilaku Disfungsional Akuntan Publik Terhadap Kualitas Audit (Studi Kasus Pada Kantor Akuntan Publik Di Bandung)." Jurnal Akuntansi 69-80. 
Suyanti, Tri, Dr. Abdul Halim, and Retno Wulandari. 2016. "Pengaruh Profesionalisme, Pengalaman, Akuntabilitas Dan Objektivitas Auditor Terhadap Kualitas Audit ( Studi Empiris Pada KAP Di Kota Malang ).” Jurnal Riset Akuntansi 4(1):1-23.

Svanström, Tobias. 2016. "Time Pressure, Training Activities and Dysfunctional Auditor Behaviour: Evidence from Small Audit Firms." International Journal of Auditing 20(1):42-51.

Tranggono, Rahadyan Probo and Andi Kartika. 2008. "Pengaruh Komitmen Organisasi Dan Profesional Terhadap Kepuasan Kerja Auditor Dengan Motivasi Sebagai Variabel Intervening (Studi Empiris Pada Kantor Akuntan Publik Di Semarang)." Jurnal Bisnis Dan Ekonomi (JBE) 15(1):80-90.

Umar, Muhammad et al. 2017. "Pressure, Dysfunctional Behavior, Fraud Detection and Role of Information Technology in the Audit Process." Australasian Accounting, Business and Finance Journal 11(4):102-15. Retrieved (http://ro.uow.edu.au/aabfj/vol11/iss4/8/).

Wulandari, Luh Gde Ayu Nidya and Made Gede Wirakusuma. 2017. "Pengaruh Independensi, Keahliat Audit, Pengalaman Dan Besaran Fee Audit Terhadap Kualitas Audit." E-Jurnal Akuntansi Universitas Udayana 21(2):942-69.

Yan, Huanmin and Shengwen Xie. 2016. "How Does Auditors' Work Stress Affect Audit Quality? Empirical Evidence From The Chinese Stock Market." China Journal of Accounting Research 9(4):305-19. Retrieved (http://dx.doi.org/10.1016/j.cjar.2016.09.001). 